\title{
7,8-Dihydroxy-3-arylcoumarin Induces Cell Death Through S-Phase Arrest in MDA-MB-231 Breast Cancer Cells
}

\author{
MUSILIYU A. MUSA ${ }^{1}$, VEERA L. D. BADISA ${ }^{2}$, LEKAN M. LATINWO ${ }^{2}$ and ELIZABETH NTANTIE ${ }^{3}$ \\ Departments of ${ }^{1}$ Chemistry and ${ }^{2}$ Biological Sciences, Florida A\&M University, Tallahassee, FL, U.S.A.; \\ ${ }^{3}$ Clark College, Vancouver, WA, U.S.A.
}

\begin{abstract}
Background/Aim: Coumarins remain one of the most versatile classes of compounds for anticancer drug design and discovery. The present study aimed to evaluate the in vitro cytotoxic activity of 7,8-Dihydroxy-3arylcoumarin derivatives (7a-i) in A549, MDA-MB-231and PC-3 cancer cell lines. Materials and Methods: Cell viability, cell-cycle progression and regulatory protein expression were evaluated using crystal violet dye-binding assay, flow cytometry and western blot analysis. Results: 7,8Diacetoxy-3-(4-nitrophenyl)coumarin (7h) showed the highest cytotoxic activity with $\mathrm{CC}_{50}$ of $7.51 \pm 0.07 \mu \mathrm{M}$ in MDA-MB-231 cell line. The mechanism of cytotoxic action indicated that 7 caused significant $(p<0.05) M D A-M B-231$ cells arrest in the $S$ phase as well as moderate cells arrest in the $G_{2} / M$ phase; confirmed by up-regulation of cyclins $A / B 1, p 21$ and CDKs 4/6, and down-regulation of cyclin E2 and CDK2 regulatory proteins. Conclusion: These results suggest that 7 could serve as a valuable template for the development of novel synthetic compounds for breast cancer treatment.
\end{abstract}

The parent compound name "Coumarin" comes from "Coumarou", a vernacular name for the tonka bean (Dipteryx odorata Wild). Coumarins (2H-1-benzopyran-2-one) are naturally-occurring oxygen heterocyclic compounds found throughout the plant and can be synthesized chemically (1). Naturally-occurring coumarins (NOCs) represent one of the largest phytochemicals occurring in the fruits, seeds, roots and leaves of many plant species; functioning as growth regulators, controllers of respiration, bacteriostats, fungistats,

Correspondence to: Musiliyu A. Musa, Ph.D., Department of Chemistry, College of Sciences and Technology, Florida A\&M University, 1530 S Martin Luther King Jr. Blvd., 219 Jones Hall, Tallahassee, FL 32307, U.S.A. Tel: +1 8505993509, Fax: +1 8505612388,e-mail: musiliyu.musa@ famu.edu

Key Words: 7,8-Dihydroxy-3-arylcoumarins, in vitro cytotoxicity, cell-cycle arrest, cyclins, cyclin-dependent kinases. as well as prophylactics against infection (2). Synthetic coumarins (SCs) on the other hand have been the focus of chemical modification of the coumarin skeleton, in order to synthesize novel analogs with improved therapeutic activity and reduced toxicity $(3,4)$. Coumarins whether NOCs or SCs possess diverse biological activities such as anticoagulant, anti-cancer, anti-tuberculosis, anti-thrombotic, anti-microbial, anti-inflammatory, anti-asthmatic, anti-viral, anti-platelet, anti-Alzheimer and anti-oxidant (5-8). These diverse pharmacological and biochemical activities are due to their structural diversity, attributed to the nature of substituent and its pattern of substitution on the core coumarin molecule (9-11). Interestingly, coumarins remain one of the most versatile class of compounds for anti-cancer drug design and discovery. They are known to target a number of pathways in cancer such as inhibition of kinases, cell-cycle phases, angiogenesis, heat shock protein (HSP90), telomerase, anti-mitotic activity, carbonic anhydrase, monocarboxylate transporters, aromatase and sulfatase (12).

For the last few years, our group has been deeply interested in the synthesis and biological evaluation of 3-Arylcoumarins as potential anti-cancer agents. Recently, we demonstrated that 7,8-Dihydroxy-3-(4-nitrophenyl)coumarin (7,8-Dihydroxylated Coumarin, DHNPC, Figure 1;1) showed higher cytotoxic activity than 7,8-Diacetoxy-3-(4-nitrophenyl)coumarin (7,8Diacetylated Coumarin, DANPC, Figure 1;2) in HepG2 cell line (13). Additionally, studies have shown that 7,8Dihydroxycoumarin (DHC, Figure 1; 3), a 7,8-Dihydroxylated coumarin, possess anti-cancer activity in different human cancer cell lines (14-16). Interestingly, coumarins are known to target a number of pathways (such as cell cycle phases) in cancer (17). As part of our ongoing investigation involving 7,8Dihydroxy-3-arylcoumarins as potential anti-cancer agents, we herein report the evaluation of the in vitro cytotoxic activity of 7,8-Dihydroxy-3-arylcoumarins (7a-i, Table I) in human lung (A549), breast (MDA-MB-231) and prostate (PC-3) cancer cell lines in comparison to current drugs, tamoxifen (TAM) and docetaxel (DOC). In addition, mode of action of the most active compound on cell-cycle progression and regulatory protein expressions were also investigated. 
Table I. The $C_{50}$ values ( $\left.\mu M\right)$ for compounds 7a-i tested in A549 (Lung), MDA-MB-231 (Breast) and Prostate (PC-3) cancer cell lines after 48 h treatment.

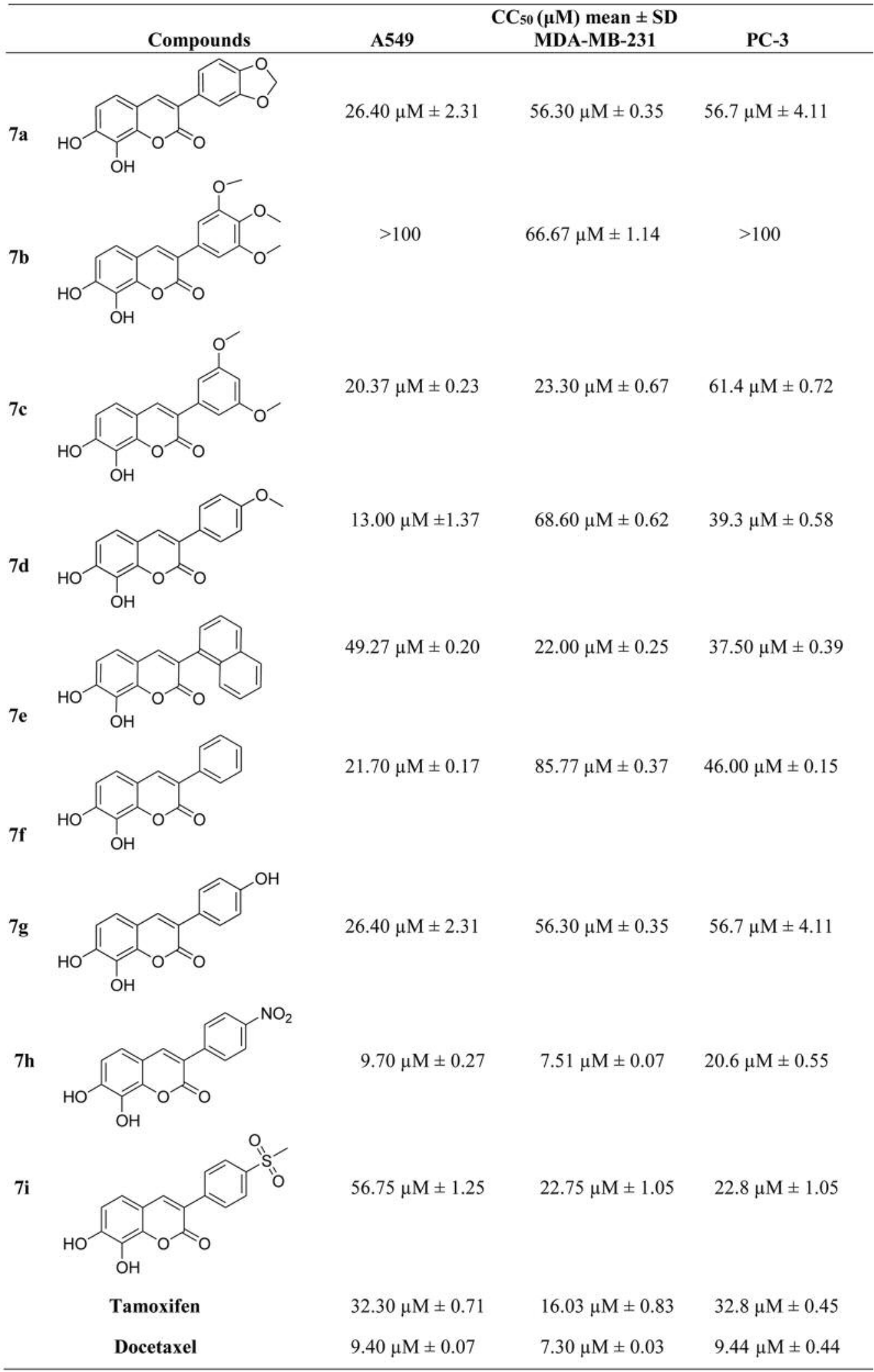

Data represent the average of triplicate from three experiments. The cytotoxic concentration $\left(\mathrm{CC}_{50}\right)$ value was determined from the graph where the live and dead cells line graphs meet in the Graph pad Prism. Drugs effects were determined after $48 \mathrm{~h}$ treatment. 


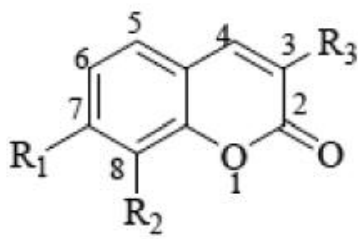

$$
\begin{array}{llll}
\text { 1; } & \mathrm{R}=\mathrm{OH} & \mathrm{R}_{1}=\mathrm{OH} & \mathrm{R}_{2}=\mathrm{C}_{6} \mathrm{H}_{5} \mathrm{NO}_{2} \\
\text { 2; } & \mathrm{R}=\mathrm{OAc} & \mathrm{R}_{1}=\mathrm{OAc} & \mathrm{R}_{2}=\mathrm{C}_{6} \mathrm{H}_{5} \mathrm{NO}_{2} \\
\text { 3; } & \mathrm{R}=\mathrm{OH} & \mathrm{R}=\mathrm{OH} & \mathrm{R}_{2}=\mathrm{H}
\end{array}
$$

Figure 1. Structures of compounds. 7,8-Dihydroxy-3-(p-nitrophenyl)coumarin (DHNPC, 1), 7,8-Diacetoxy-3-(p-nitrophenyl)coumarin (DANPC, 2), and 7,8-Dihydroxycoumarin $(\mathrm{DHC}, \mathbf{3})$.

\section{Materials and Methods}

Chemicals. F12K and DMEM-F12 media, penicillin-streptomycin anti-biotic solution $(100 \times)$, fetal bovine serum (FBS), trypsin-EDTA solution $(1 \times)$, phosphate buffered saline (PBS), 50\% glutaraldehyde, crystal violet, IGEPAL CA-630, propidium iodide, tamoxifen, docetaxel and RNase were obtained from Sigma-Aldrich company (St. Louis, MO, USA). Total protein cell lysis buffer was obtained from AMRESCO (Solon, OH, USA). The EZ Block protease inhibitor cocktail (BioVision, Milpitas, CA, USA) was obtained from VWR International (Suwanee, GA, USA). p21 Waf1/Cip1(12D1) rabbit mAb 2947, CDK2 rabbit mAb 2556, cyclin A2 mouse mAb 4639, cyclin $\mathrm{B} 1$ rabbit mAb 12231, cyclin $\mathrm{E} 2 \mathrm{Ab} 4132$, CDK 4 rabbit mAb 12790, and CDK6 mouse mAb 3136 were purchased from Cell Signaling Technology (Danvers, MA, USA).

Cell line maintenance. The human lung (A549), breast (MDA-MB$231)$ and prostate (PC-3) cancer cell lines were obtained from the American Type Culture Collection (ATCC, Rockville, MD, USA) and cultured as per the guidelines supplied. The cells were maintained in F12K (A549, PC-3) and DMEM-F12 (MDA-MB231) media containing 100 units of penicillin/ml, $100 \mu \mathrm{g}$ of streptomycin/ml, $2 \mathrm{mM}$ L-glutamine and $10 \% \mathrm{FBS}$ in T-75 $\mathrm{cm}^{2}$ flasks at $37^{\circ} \mathrm{C}$ in a $5 \% \mathrm{CO}_{2}$ incubator.

Treatment and measurement of cell viability. The cells (MRC-9, MDA-MB-231 or PC-3) were plated at a density of $5 \times 10^{4}$ cells per well in a polystyrene, flat bottom 24-well microtiter plate (Corning Costar, Rochester, NY, USA) in cell type pertaining medium containing $10 \%$ FBS and allowed to stabilize overnight in a $5 \%$ $\mathrm{CO}_{2}$ incubator at $37^{\circ} \mathrm{C}$. Afterwards, the cells were treated with compounds (7a-i) at different concentrations of $(0,10,25,50,75$ and $100 \mu \mathrm{M}$ ) in a final volume of $1 \mathrm{ml}$ per well in triplicate wells for each treatment for $48 \mathrm{~h}$ at $37^{\circ} \mathrm{C}$ in a $5 \% \mathrm{CO}_{2}$ incubator. All studies were repeated at least twice. At the end of incubation period, the viability was evaluated by crystal violet dye uptake assay and cytotoxic concentration $\left(\mathrm{CC}_{50}\right)$ was calculated according to our previously reported method (6). Glutaraldehyde (400 $\mu \mathrm{l}$ of $0.25 \%)$ was added to each well and incubated for $30 \mathrm{~min}$ at room temperature (RT) to fix the cells. The glutaraldehyde $(0.07 \%$ final concentration in the well) in the crystal violet dye staining assay procedure fixed the viable cells after treatment with the compound. The plates were rinsed with water to wash off the dead cells and dried under airflow inside a laminar hood for 5-10 min. Crystal violet ( $400 \mu \mathrm{l}$ of $0.1 \%$ ) was added to each well, incubated for 15 min, washed and dried. To solubilize the dye, $1 \mathrm{ml}$ of $0.05 \mathrm{M}$ sodium phosphate solution (monobasic) in $50 \%$ ethyl alcohol was

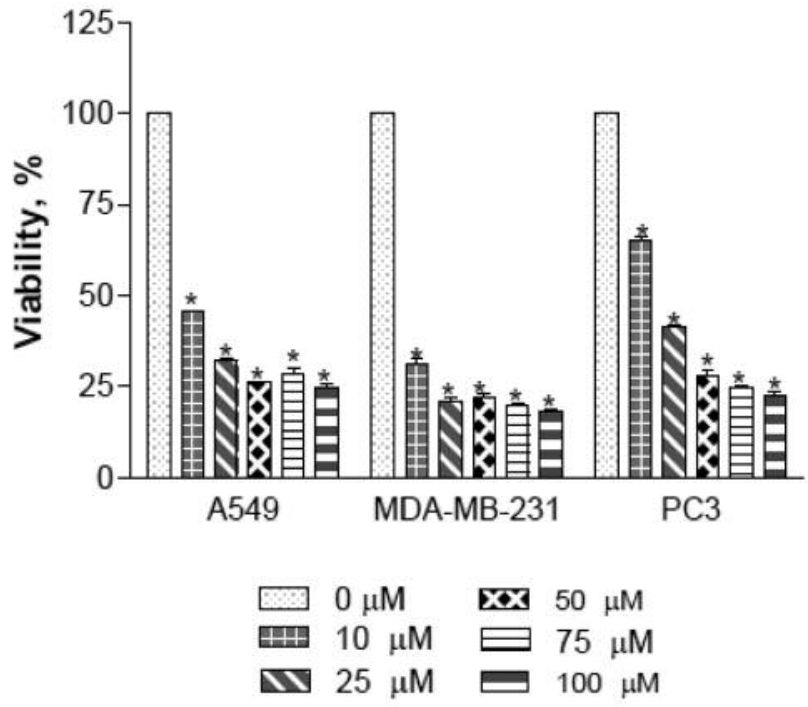

Figure 2. The cytotoxic activity of the most active compound 7 . The cells were treated with compound $7 \mathrm{~h}$ for $48 \mathrm{~h}$ and the viability was measured by crystal violet binding assay.

added to each well and the plates were read at $540 \mathrm{~nm}$ in a plate reader (Bio-Tek EL800 Plate Reader, Winooski, VT, USA). The mean absorbance value of control samples was considered as $100 \%$ and the treated sample percentages were calculated by comparing the treated samples absorbance with the control.

Cell cycle analysis. Cell cycle analysis was carried out according to our previous report (6) by treating $1.3 \times 10^{6}$ MDA-MB-231 cells / T25 flask in complete medium, in triplicate flasks for each treatment with $7 \mathrm{~h}(0,5,10 \mu \mathrm{M})$ for $24 \mathrm{~h}$. At the end of incubation, cells were trypsinized, pelleted, washed with PBS and resuspended in $1 \mathrm{ml}$ of Vindelov's reagent (PBS $1 \times$ containing ribonuclease A $(10 \mu \mathrm{g} / \mathrm{ml})$, propidium iodide $(7.5 \mu \mathrm{g} / \mathrm{ml})$ and IGEPAL CA- $630(1 \mu \mathrm{l} / \mathrm{ml})$. The cells were stained at $4^{\circ} \mathrm{C}$ overnight and analyzed using a flow cytometer for cell cycle analysis at different phases, at a low flow rate of $\sim 150$ cells/sec or less.

Preparation of samples for western blot. Approximately $4.4 \times 10^{6}$ MDA-MB-231 cells were plated in T-175 $\mathrm{cm}^{2}$ flasks in complete DMEM-F12 medium and allowed to stabilize overnight. The cells 
were treated with $7 \mathrm{~h}$ at different concentrations $(0,20$ and $40 \mu \mathrm{M})$ and incubated for $24 \mathrm{~h}$ in a $5 \% \mathrm{CO}_{2}$ incubator at $37^{\circ} \mathrm{C}$. At the end of incubation, the cells were trypsinized and pelleted by centrifuging at 2,500 rpm for $5 \mathrm{~min}$. The control and treated cell pellets were suspended in $100 \mu \mathrm{l}$ of total protein cell lysis buffer (AMRESCO, Solon, OH, USA) containing EZBlock protease inhibitor cocktail (BioVision, Milpitas, California, USA) and incubated on ice for 30 min with periodic vortexing. The tubes were centrifuged at 14,000 $\mathrm{g}$ for $20 \mathrm{~min}$ at $4^{\circ} \mathrm{C}$. The supernatant was transferred to a fresh tube and stored at a $-80^{\circ} \mathrm{C}$ freezer till further use.

Protein estimation. The protein concentration of cell lysates was quantitatively measured using the Pierce BCA Protein Assay (Life technologies, Grand Island, NY, USA). Different concentrations of albumin standard (BSA) and working reagent were prepared according to the kit's manual. Each standard concentration and 1:10 diluted cell lysate $(25 \mu \mathrm{l})$ were pipetted in triplicate wells in a 96-well plate and $200 \mu \mathrm{l}$ of working reagent was added to each well. The plate was incubated at $37^{\circ} \mathrm{C}$ for $30 \mathrm{~min}$ and then read at $540 \mathrm{~nm}$ in a plate reader (Bio-Tek EL800 Plate Reader, Winooski, VT, USA). The protein concentration of cell lysate was determined using the generated standard curve by the $K C$ Junior plate reader software.

Western blot analysis. The protein $(30 \mu \mathrm{g})$ from each sample in $1 \mathrm{X}$ SDS gel loading buffer was loaded into $15 \%$ SDS PAGE, run at $80 \mathrm{~V}$ and electro-transferred to a nitrocellulose membrane at $30 \mathrm{~V}$ for $16 \mathrm{~h}$. The western blot analysis was performed according to manual instructions by Cell Signaling Technology. The nitrocellulose membrane was washed with $25 \mathrm{ml}$ of Tris buffered saline with $0.5 \%$ Tween $20(\mathrm{TBS} / \mathrm{T})$ buffer for $5 \mathrm{~min}$ at RT. The membrane was incubated in $10 \mathrm{ml}$ of blocking buffer (5\% Non-fat milk in TBS/T buffer) for $1 \mathrm{~h}$ at $\mathrm{RT}$, and incubated with a primary antibody (1:1,000 dilution) in $10 \mathrm{ml}$ primary antibody dilution buffer with gentle agitation overnight at $4^{\circ} \mathrm{C}$. Later, the membrane was washed with $15 \mathrm{ml}$ of $\mathrm{TBS} / \mathrm{T}$ for $5 \mathrm{~min}$ each $(3 \times)$, incubated with the appropriate HRP-conjugated secondary antibody $(1: 2,000)$ in $10 \mathrm{ml}$ of blocking buffer with gentle agitation for $1 \mathrm{~h}$ at RT and then washed for $5 \mathrm{~min}$ each $(3 \times)$ with $15 \mathrm{ml}$ of TBS/T. The membrane was then incubated with $10 \mathrm{ml}$ LumiGLO $^{\circledR}$ (Cell Signaling Technology, Danvers, MA, USA) $\left(0.5 \mathrm{ml} 20 \times\right.$ LumiGLO $^{\circledR}, 0.5 \mathrm{ml}$ $20 \times$ Peroxide and $9.0 \mathrm{ml}$ Milli-Q water) with gentle agitation for $5 \mathrm{~min}$ at RT. The excess developing solution was drained from the membrane, and the membrane was wrapped in plastic wrap followed by imaging using ChemiDoc machine. The density of the bands on the blot was quantified using the Un-Scan-It get TM program (Silk scientific, Inc., Orem, UT, USA).

Statistical analysis. The data were presented as mean \pm standard deviation $(\mathrm{SD}, \mathrm{n}=3)$. All treated cells data were presented as percentage values in comparison to the untreated control (100\%). The data were analyzed for significance by one-way ANOVA, and then compared by Dunnett's multiple comparison tests, using the GraphPad Prism Software, version 3.00 (GraphPad Software, Inc., San Diego, CA, USA). Differences from the respective untreated control were considered statistically significant when $p<0.05$. The viability and $\mathrm{CC}_{50}$ graphs were plotted in Prizm 3.00 software (GraphPad Software, Inc., San Diego, CA, USA). The $\mathrm{CC}_{50}$ value was deduced from the point of the graph where the live and dead cells lines meet (the dose at which $50 \%$ of the cells dies) using the Prizm 5 software.

\section{Results}

Cytotoxic activity of compounds $7 a-i$ in cancer cell lines. In the present investigation, the in vitro cytotoxic activity of 7,8-Dihydroxy-3-arylcoumarins (7a-i) at different concentrations $(0,25,50,75$ and $100 \mu \mathrm{M})$ were analyzed in human lung (A549), breast (MDA-MB-231) and prostate (PC-3) cancer cell lines after treatment for $48 \mathrm{~h}$, using crystal violet dye binding assay. The $\mathrm{CC}_{50}$ values of $7 \mathrm{a}-\mathrm{i}$, TAM and DOC are shown in Table I. The in vitro cytotoxic activity results indicate that $7 \mathrm{~h}$ containing $p$-nitrophenyl-group at the Carbon-3 (C-3) position showed the highest cytotoxic activity in $\mathrm{A} 549\left(\mathrm{CC}_{50}=9.70 \pm 0.27 \mu \mathrm{M}\right), \mathrm{MDA}-\mathrm{MB}-231$ $\left(\mathrm{CC}_{50}=7.51 \pm 0.07 \mu \mathrm{M}\right)$ and $\mathrm{PC}-3\left(\mathrm{CC}_{50}=20.60 \pm 0.55 \mu \mathrm{M}\right)$ cancer cell lines with respect to untreated control cells (Figure 2). Overall, 7h showed the highest cytotoxic activity $\left(\mathrm{CC}_{50}=7.51 \mu \mathrm{M}\right)$ in MDA-MB-231 cell line. Comparison of the cytotoxic activity of $7 \mathrm{~h}$ with TAM and DOC (currently used anti-cancer drugs) revealed that (i) $7 \mathrm{~h}$ showed higher cytotoxic activity in A549 (three-fold), MDA-MB-231 (twoand-a-half fold) and PC-3 (one-and-a-half fold) cell lines compared to TAM, (ii) $7 \mathrm{~h}$ and docetaxel showed similar cytotoxic activity in A549 and MDA-MB-231 cell lines, and (iii) $7 \mathrm{~h}$ showed two-fold decrease in cytotoxic activity compared to DOC in PC-3 cell line (Table I).

Compound 7 induced cell cycle arrest in S-phase in breast cancer cells. To explore the molecular target leading to the higher cytotoxic activity of the most active compound $7 \mathrm{~h}$ in MDA-MB-231 cells, we evaluated the effect of this compound $(5,10 \mu \mathrm{M})$ on cell cycle progression after $24 \mathrm{~h}$ treatment. The control and treated cells were stained with propidium iodide (PI) and the percentage of cells in each cell cycle phase was analyzed using a flow cytometer. As shown in Figure 3, the percentage of cells at $\mathrm{S}$ phase increased significantly from $20.2 \pm 0.6 \%$ (control) to $25.0 \pm 0.3 \%(5 \mu \mathrm{M})$ and $33.1 \pm 1.0 \%(10 \mu \mathrm{M})$ in a concentration-dependent manner and moderately at $\mathrm{G}_{2} / \mathrm{M}$ phase from $41.2 \pm 0.7 \%$ (control) to $44.2 \pm 0.7 \%(5 \mu \mathrm{M})$ with respect to the untreated control cells.

Compound 7 modulated $S$ phase regulatory proteins in breast cancer cells. Based on the above finding that $7 \mathrm{~h}$ modulates $\mathrm{S}$ phase cell cycle arrest, we evaluated the expression of cell cycle regulatory proteins (cyclins A, B, and E; CDKs 2, 4, and 6; and CDK inhibitor (p21 Waf1/Cip1(12D1) $)$ in treated MDAMB-231 cells $(5,10 \mu \mathrm{M})$ after $24 \mathrm{~h}$ treatment. Western blotting analysis results showed that the expression levels of cyclins A2 (154.8\% 2.5 at $5 \mu \mathrm{M}$ and $219.6 \% \pm 6.2$ at $10 \mu \mathrm{M}$; Figure $4 \mathrm{~A})$, cyclins B1(135.2\% \pm 0.3 at $5 \mu \mathrm{M}$ and $116.7 \% \pm 0.4$ at $10 \mu \mathrm{M}$; Figure $4 \mathrm{~B}), \mathrm{CDK} 4(129.1 \% \pm 0.9$ at $5 \mu \mathrm{M}$ and $213.9 \% \pm 1.8$ at $10 \mu \mathrm{M}$; Figure 4E) and CDK $6(143.9 \% \pm 0.7$ at $5 \mu \mathrm{M}$ and $121.7 \% \pm 1.0$ at $10 \mu \mathrm{M}$; Figure $4 \mathrm{~F}$ ) proteins as well as CDK inhibitor $\mathrm{p} 21^{\text {Waf1/Cip1(12D1) }}(139.4 \% \pm 0.5$ at $5 \mu \mathrm{M}$ and 

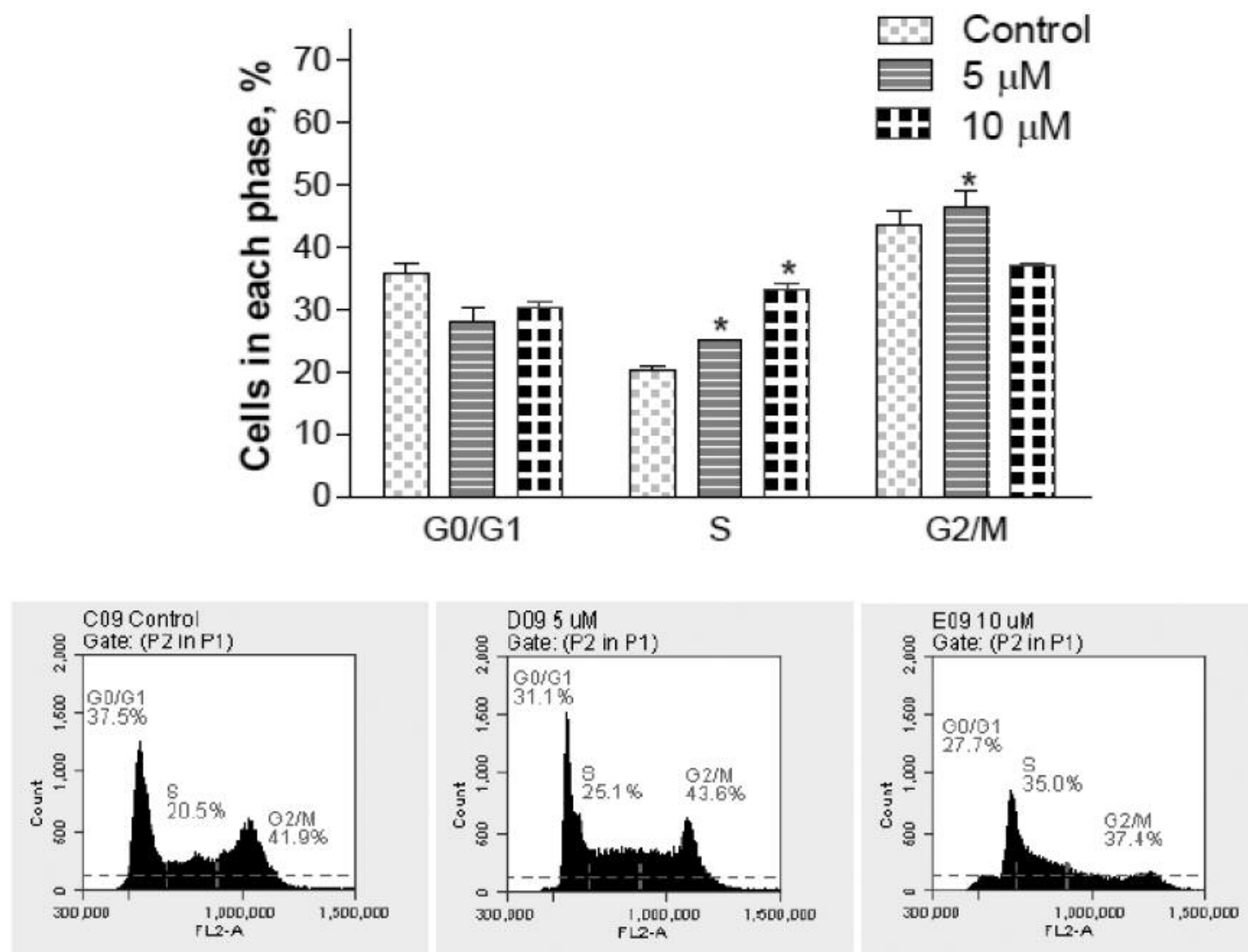

Figure 3. Effect of compound $7 \mathrm{~h}$ on cell-cycle progression in MDA-MB-231 cells. The cells were treated with compound $7 \mathrm{~h}$ for $24 \mathrm{~h}$ and cells in each phase were analyzed by flow cytometry. Data are represented as mean and $S D, n=3$. *Statistically significant difference from the control $(p<0.05)$ using Dunnett's multiple comparison test.

$130.2 \% \pm 0.2$ at $10 \mu \mathrm{M}$; Figure $4 \mathrm{G}$ ) were up-regulated compared to untreated control cells (100\%). Furthermore, the expression levels of cyclin E2 $(100.8 \% \pm 0.5$ at $5 \mu \mathrm{M}$ and $88.6 \% \pm 0.1$ at $10 \mu \mathrm{M}$; Figure $4 \mathrm{C})$ and $\mathrm{CDK} 2(86.7 \% \pm 0.1$ at $5 \mu \mathrm{M}$ and $88.2 \% \pm 0.5$ at $10 \mu \mathrm{M}$; Figure $4 \mathrm{D}$ ) were down-regulated compared to untreated control cells (100\%).

\section{Discussion}

Coumarins are important naturally-occurring compounds used in drug discovery and still remain as one of the most versatile class of compounds against cancer cells. As part of our ongoing investigation involving 7,8-Dihydroxy-3-arylcoumarins as potential cytotoxic agents, we herein report that $7 \mathrm{~h}$ containing $p$-nitrophenyl- group at the C-3 position showed the highest cytotoxic activity in A549, MDA-MB-231 and PC-3 cancer cell lines with respect to untreated control cells (Table I). Based on structure activity relationship study (SARs), the presence of $p$ nitrophenyl- group (containing $\mathrm{NO}_{2}$, strong electron- withdrawing group) enhanced the cytotoxic activity of 7,8Dihydroxy-3-arylcoumarins significantly compared to benzo[d][1,3]dioxol-6-yl-; 3, 4, 5-trimethoxy phenyl-; 3, 5dimethoxyphenyl-; 4-methoxyphenyl-; naphthalenyl-; phenyl-; 4-hydroxyphenyl-; 4-(methyl sulfonyl)phenyl- groups in A549, MDA-MB-231 and PC-3 cancer cell lines (Table I). This finding is consistent with previous finding from our research group indicating that $p$-nitrophenyl- group is a good structural feature for enhancing the cell-specific cytotoxic activity of 7,8Dihydroxy-3-arylcoumain in certain types of cancer cell lines (18). Furthermore, comparison of the cytotoxic activity of $7 \mathrm{~h}$ with TAM or DOC revealed that $7 \mathrm{~h}$ showed a higher cytotoxic activity in the order of A549>MDA-MB-231>PC-3 cancer cell lines compared to TAM, similar cytotoxic activity in A549 and MDA-MB-231 cell lines and lower cytotoxic activity in PC-3 cell line compared to DOC (Table I).

Coumarins have been reported to exert their cytotoxic activity by arresting cells in different phases $\left(\mathrm{G}_{0} / \mathrm{G}_{1}\right.$ or $\mathrm{S}$ or $\mathrm{G}_{2} / \mathrm{M}$ phase) of the cell cycle depending on the cell line (19). 
A

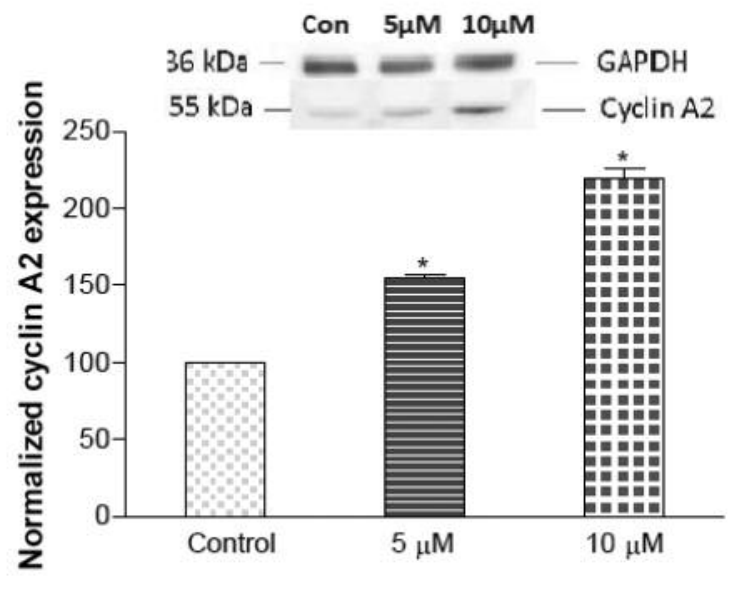

C

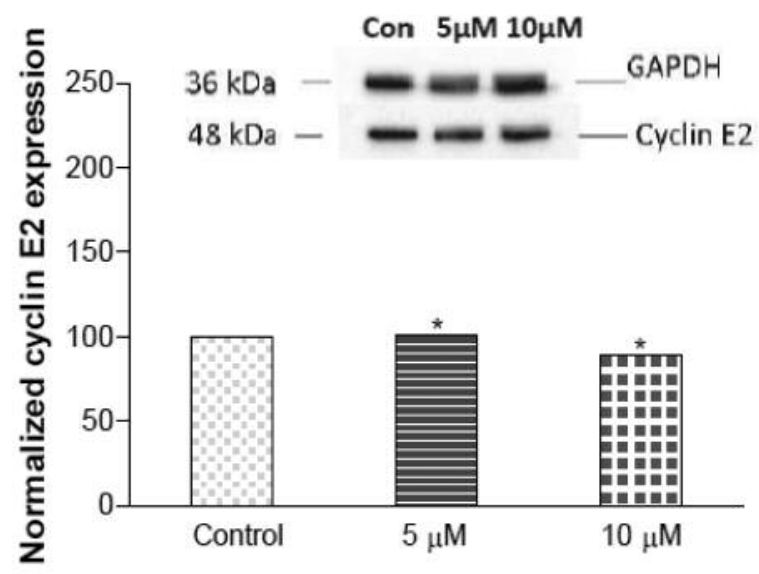

E

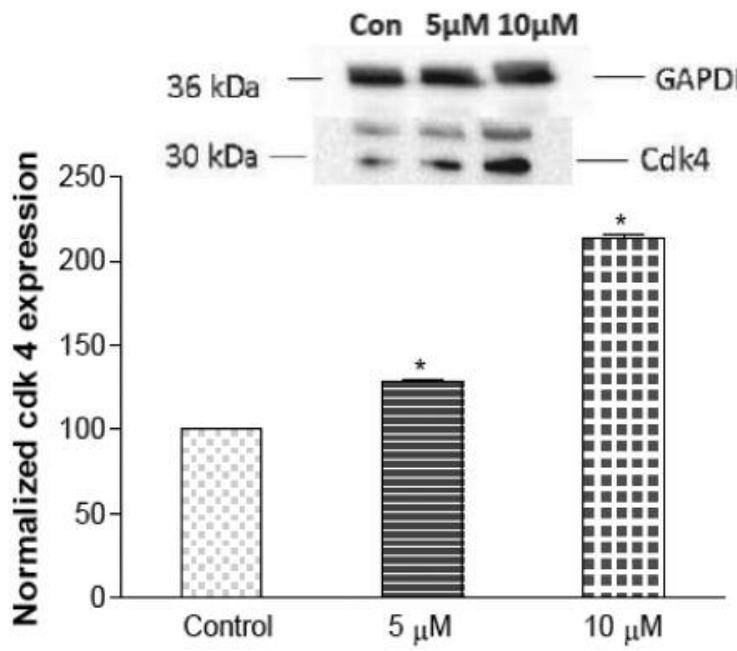

B

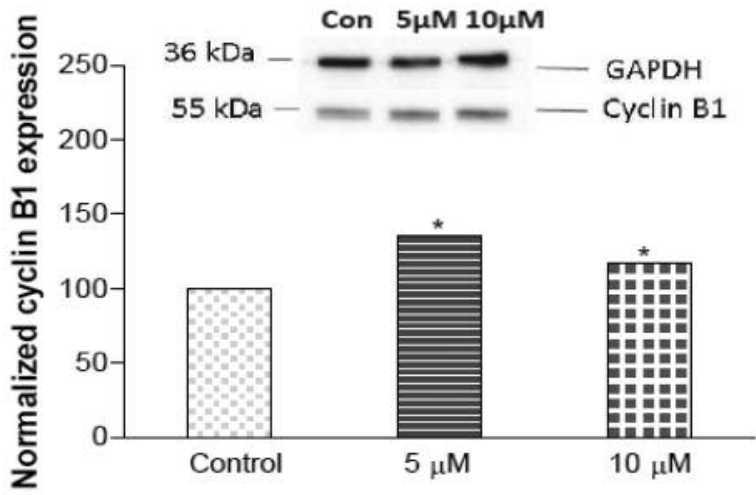

D

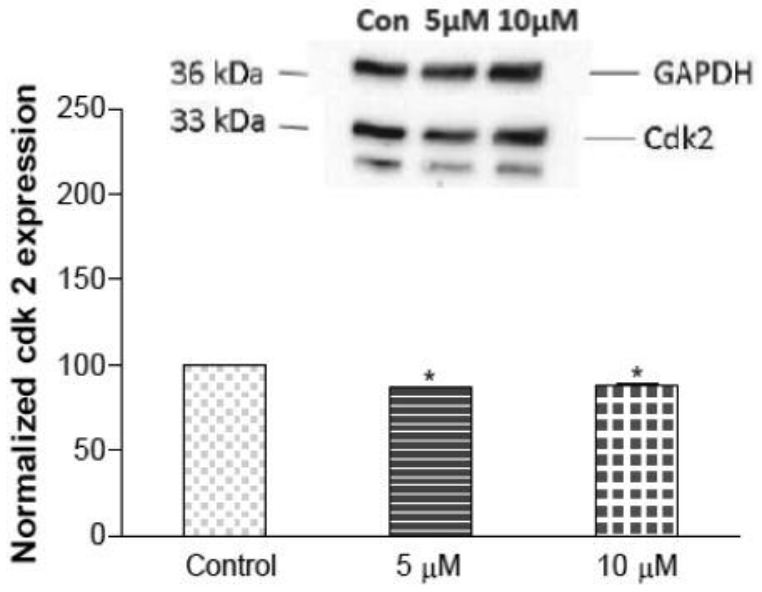

F

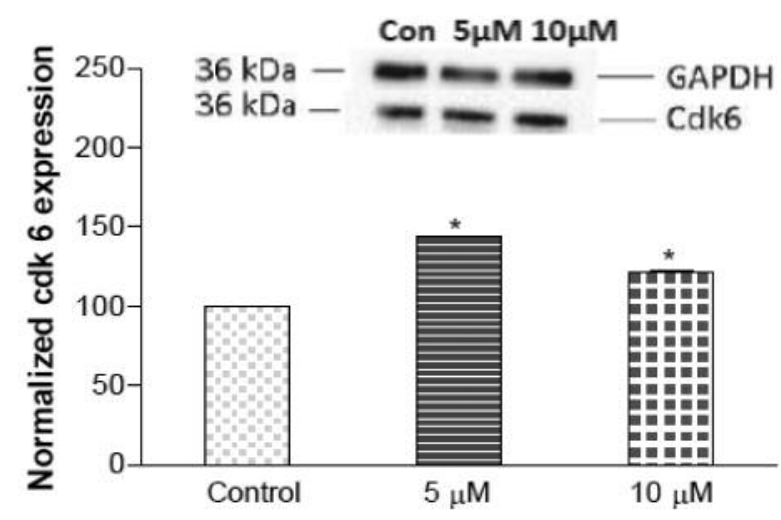

Figure 4. Continued 


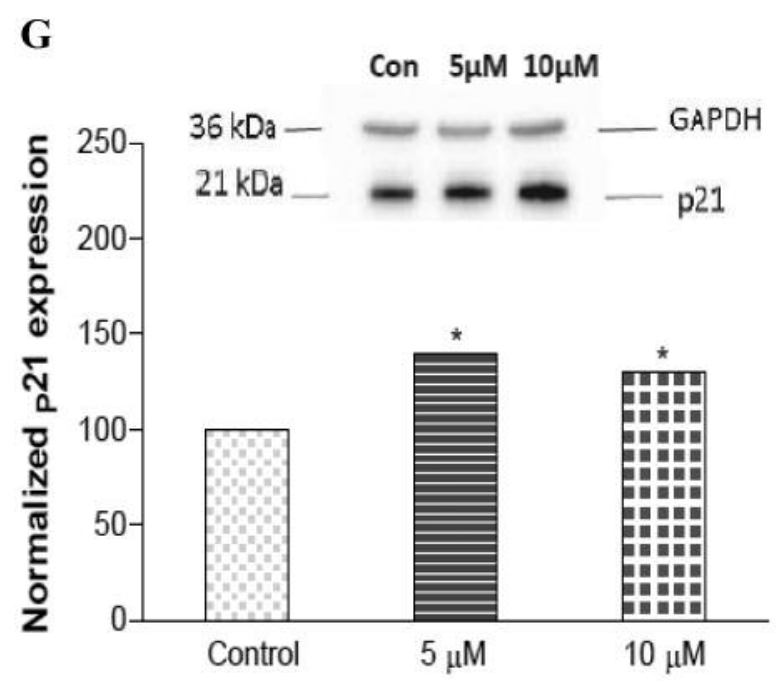

Figure 4. Effect of compound $7 \mathrm{~h}$ on cell-cycle regulatory proteins. MDA$M B-231$ cells were treated with compound $7 \mathrm{~h}$ for $24 \mathrm{~h}$ and expression of cyclins A, B, and E; CDKs 2, 4, and 6; and $221^{\text {Wafl/Cipl(12D1) proteins was }}$ measured using western blotting. Data are represented as mean $\pm S D, n=3$.

Cell cycle is a sequence of complex events by which cells grow and divide. Therefore, control of cell-cycle progression may be a successful strategy for halting tumor growth since cancer cells show uncontrolled growth (20). In the present investigation, $7 \mathrm{~h}$ arrested MDA-MB-231 cells in $\mathrm{S}$ phase in a concentration-dependent manner with respect to the untreated control cells; indicating that one of the mechanisms by which $7 \mathrm{~h}$ induced cell death in MDA-MB-231 cells is by inhibition of DNA synthesis (Figure 3). The progression of cells through the different phases of cell cycle is regulated by cyclins and CDK (cyclin dependant kinases) proteins. These cell-cycle regulatory proteins are potential molecular targets for cancer therapy/prevention because their functions are regulated differently in cancer cells and normal cells (21). Cyclin A and CDK2 are known to play an important role in the regulation of DNA synthesis during cell-cycle progression at $\mathrm{S}$ phase and are deregulated or up-regulated in several cancers such as breast, liver, and lung $(22,23)$. Furthermore, previous reports have shown that the 1) synthesis of cyclin A starts in $\mathrm{S}$ phase and reaches maximal levels at the $S / G_{2}$ transition; 2) cyclin B starts at the end of $S$ phase and reaches maximal levels as the cell enters into phase $M$; and 3) cyclin $E$ begins in mid-phase $G_{1}$, reaches maximal levels at the $G_{1} / S$ transition and is degraded during $S$ phase (24). The $S$ phase cell-cycle arrest has been reported to occur with the loss of Cdk2 activity due to up-regulation of p21 Waf1/Cip1(12D1); a well-known inhibitor of Cdk 2 (2527). CDK 4 and CDK6 have been reported to help drive the progression of cells into the S (DNA synthetic) phase of the cell cycle in mammalian cells (28). Therefore, based on western blotting analysis (Figure 4), it can be speculated that $7 \mathrm{~h}$ induced cell death in MDA-MB-231 cells by altering expression of cell cycle regulatory proteins, which govern the $\mathrm{S} / \mathrm{G}_{2}$ phase cell-cycle progression.

In conclusion, our studies demonstrated that $7 \mathrm{~h}$ containing the $p$-nitrophenyl- group at Carbon-3 position showed the highest cytotoxic activity in MDA-MB-231 cell line. The cytotoxic mode of action of $7 \mathrm{~h}$ in MDA-MB-231 cells was associated with cell cycle arrest at $\mathrm{S}$ phase through upregulation of cyclins $\mathrm{A}$ and B1, CDKs $4 / 6$ and p21 Waf1/Cip1(12D1), and down-regulation of cyclin E1 and CDK2 regulatory proteins. This compound also showed higher cytotoxic potency than the standard anti-cancer drug, TAM. Thus, the present investigation provided a new insight on how $7 \mathrm{~h}$ induced cell death in MDA-MB-231 cell line, which may be helpful in the development of future promising therapeutic agents for breast cancer treatment.

\section{Conflicts of Interest}

The Authors declare that they have no financial or non-financial competing interests.

\section{Acknowledgements}

The Authors would like to acknowledge Florida A\&M University TITLE III PROGRAM for their financial support.

\section{References}

1 Murray RDH: The naturally occurring coumarins. Prog Chem Org Nat Prod 83: 1-673, 2002.

2 Lacy A and O'Kennedy R: Studies on coumarins and coumarinrelated compounds to determine their therapeutic role in the treatment of cancer. Curr Pharm Des 10: 3797-3811, 2004.

3 Kabeya LM, de Marchi AA, Kanashiro A, Lopes NP, da Silva $\mathrm{CH}$, Pupo MT and Lucisano-Valim YM: Inhibition of horseradish peroxidase catalytic activity by new 3phenylcoumarin derivatives: synthesis and structure-activity relationships. Bioorg Med Chem 15: 1516-1524, 2007.

4 Khoobi M, Emami S, Dehghan G, Foroumadi A, Ramazani A and Shafiee A: Synthesis and free radical scavenging activity of coumarin derivatives containing a 2-methylbenzothiazoline motif. Arch Pharm (Weinheim) 344: 588-594, 2011.

5 Paul K, Bindal S and Luxami V: Synthesis of new conjugated coumarin-benzimidazole hybrids and their anticancer activity. Bioorg Med Chem Lett 23: 3667-3672, 2013.

6 Musa MA, Latinwo LM, Joseph MY and Badisa VL: Identification of 7,8-Diacetoxy-3-arylcoumarin derivative as a selective cytotoxic and apoptosis-inducing agent in a human prostate cancer cell line. Anticancer Res 37: 6005-6014, 2017.

7 Sandhu S, Bansal Y, Silakari O and Bansal G: Coumarin hybrids as novel therapeutic agents. Bioorg Med Chem 22: 3806-3814, 2014.

8 Venugopala KN, Rashmi V and Odhav B: Review on natural coumarin lead compounds for their pharmacological activity. Biomed Res Int 2013: 1-14, 2013. 
9 Musa MA, Badisa V, Latinwo LM, Cooperwood J, Sinclair A and Abdullah A: Cytotoxic activity of new acetoxycoumarin derivatives in cancer cell lines. Anticancer Res 31: 2017-2022, 2011 .

10 Kostova I: Studying plant-derived coumarins for their pharmacological and therapeutic properties as potential anticancer drugs. Expert Opin. Drug Discov 2: 1605-1618, 2007.

11 Kostova I, Raleva S, Genova P and Argirova R: Structureactivity relationships of synthetic coumarins as HIV-1 inhibitors. Bioinorg Chem Appl 2006: 68274-68283, 2006.

12 Thakur A, Singla R and Jaitak V: Coumarins as anticancer agents: a review on synthetic strategies, mechanism of action and SAR studies. Eur J Med Chem 101: 476-495, 2015.

13 Musa MA, Gbadebo AJ, Latinwo LM and Badisa VL: 7,8Dihydroxy-3-(4-nitrophenyl)coumarin induces cell death via reactive oxygen species-independent S-phase cell arrest. J Biochem Mol Toxic e22203, 2018.

14 Raj HG, Parmar VS, Jain SC, Goel S, Himanshu P, Malhotra S, Singh A, Olsen CE and Wengel J: Mechanism of biochemical action of substituted 4-methylbenzopyran-2-ones. Part I: Dioxygenated 4-methyl coumarins as superb antioxidant and radical scavenging agents. Bioorg Med Chem 6: 833-839, 1998.

15 Miri R, Nejati M, Saso L, Khakdan F, Parshad B, Mathur D, Parmar VS, Bracke ME, Prasad AK, Sharma SK and Firuzi O: Structure-activity relationship studies of 4-methylcoumarin derivatives as anticancer agents Pharm Biol 54: 105-110, 2016.

16 Goel A, Prasad AK, Parmar VS, Ghosh B and Saini N: 7,8,Dihydroxy-4-methylcoumarin induces apoptosis of human lung adenocarcinoma by ROS-independent mitochondrial pathway through inhibition of ERK/MAPK signaling, FEBS Lett 581: 2447-2454, 2007.

17 Thakur A, Singla R and Jaitak V: Coumarins as anticancer agents: a review on synthetic strategies, mechanism of action and SAR studies. Eur J Med Chem 101: 476-495, 2015.

18 Musa MA, Latinwo LM, Virgile C, Badisa VL and Gbadebo AJ: Synthesis and in vitro evaluation of 3-(4 nitrophenyl)coumarin derivatives in tumor cell lines. Bioorg Chem 58: 96-103, 2015.
19 Widelski J, Kukula-Koch W, Baj T, Kedzierski B, Fokialakis N, Magiatis P, Pozarowski P, Rolinski J, Graikou K, Chinou I and Skalicka-Wozniak K: Rare coumarins induce apoptosis, G1 cell block and reduce RNA content in HL60 cells. Open Chem 15: 1-6, 2017.

20 Buolamwini JK: Cell cycle molecular targets in novel anticancer drug discovery. Curr Pharm Des 6: 379-392, 2000.

$21 \mathrm{Lu}$ X, Jung J, Cho HJ, Lim DY, Lee HS, Chun HS, Kwon DY and Park JH: Fisetin inhibits the activities of cyclin-dependent kinases leading to cell cycle arrest in HT-29 human colon cancer cells. J Nutr 135: 2884-2890, 2005.

22 Takuwa N and Takuwa Y: Regulation of cell cycle molecules by the Ras effector system. Mol Cell Endocrinol 177: 25-33, 2001.

23 Dachineni R, Ai G, Kumar DR, Sadhu SS, Tummala H and Bhat GJ: Cyclin A2 and CDK2 as novel targets of aspirin and salicylic acid: a potential role in cancer prevention. Mol Cancer Res 14: 241-252, 2016.

24 Pines J: Cyclin and cyclin-dependent kinases: theme and variations. Adv Cancer Res 66: 181-212, 1995.

25 Laezza C, Pisanti S, Crescenzi E and Bifulco M: Anandamide inhibits Cdk2 and activates Chk1 leading to cell cycle arrest in human breast cancer cells. FEBS Lett 580: 6076-6082, 2006.

26 Borriello A, Cucciolla V, Oliva A, Zappia V and Della Ragione F: p27Kip1 metabolism: a fascinating labyrinth. Cell Cycle 6: 1053-1061, 2007.

27 Abukhdeir AM and Park BH: P21 and p27: roles in carcinogenesis and drug resistance. Expert Rev Mol Med 10: e19, 2008.

28 Wolter F, Akoglu B, Clausnitzer A and Stein J: Down-regulation of the cyclin D1/Cdk4 complex occurs during resveratrol-induced cell cycle arrest in colon cancer cell lines. J Nutr 131: 2197-2203, 2001.

Received October 3, 2018

Revised October 17, 2018

Accepted October 18, 2018 